\title{
Vitamin D Deficiency and its Effects on Tooth Structure and pulpal changes
}

\author{
Lingam Amara Swapna*, Rasheed Abdulsalam \\ Faculty of Dentistry, Lincoln University College, Kota Bharu, Malaysia
}

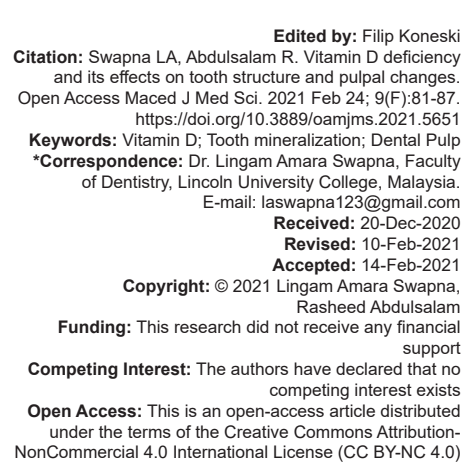

\section{Abstract}

Vitamin $D$ is a steroid hormone that produced primarily by sunlight exposure or obtained from dietary sources, including supplements. The persons who are normally at risk of Vitamin D deficiency are those with scarce of sun exposure and diminished intestinal absorption or limited oral intake. Teeth are nothing but mineralized structure which is enclosed by alveolar bone and are developed by 3 different hard tissues such as dentin, enamel, and cementum. Vitamin D plays a predominant vital part in the tooth and bone mineralization, and it can result in rachitic tooth when the levels get unregulated. Studies suggest that Vitamin D deficiency causes hypocalcified dentin and delayed tooth eruption; thus, representing that Vitamin D has a crucial role in dentin formation as well. The beneficia effects of vitamin D on oral health are not only limited to the direct effects on the tooth mineralization but are also applied through ability to stimulate the production of anti-microbial peptides. In this article, we will briefly discuss the influence on Vitamin D level on the oral and pulpal health.

\section{Introduction}

Vitamin $D$ is a steroid hormone produced primarily by sunlight exposure, but it can also be obtained by dietary and diet supplements [1], [2], [3]. The presence of vitamin $D$ are rare in raw foods and it can be detected in fish oils (including cod liver oil) and oily fish (which includes herring, mackerel, and salmon) [2]. Vitamin D is the collective term for Vitamin D2 and D3. Whereas Vitamin D2 is produced by exposing the ergosterol from yeast to ultraviolet radiation and Vitamin D3 produced by exposing the 7-dehydrocholesterol from lanolin to ultraviolet radiation [4] displaying the biological processes of cholecalciferol (Vitamin D3) and is produced in human bodies. Evaluation of serum 25-hydroxyvitamin D $(25[\mathrm{OH}] \mathrm{D})$ is a generally recognized biomarker study of Vitamin D levels [3]. Vitamins are stated as none other than organic compounds that are needed in minute quantities for the purpose of keeping normal health maintained for the organisms [2].

As per the perception of Holick and Chen [2] Vitamin $D$ basically behaves like a hormone; and the endocrine action of it is helpful in promoting the phosphate homeostasis as well as serum calcium with the help of intestinal absorption regulation. According to the statement of Morris and Anderson [5], Vitamin D as well acts alike paracrine and autocrine agent, cell maturation, cell maturation, regulating the process of cell differentiation, and finally innate the process of immune system. On regards to the statement made by Morris and Anderson [5]; Vitamin D's cellular activities have been mediated through receptor of Vitamin $D$, that is, (VDR), this is nothing but a receptor molecule which is capable of binding into an active form of Vitamin D. In accordance to the view point of Richard et al. [6], the activities of Vitamin $D$ are based on the VDR regulation for its genomic kind of impacts as well as on the membrane connecting proteins to the non-genomic impacts like signaling pathways. This wide activity is because of the fact or reason that this kind of vitamin tends to modulate the expression of some amount of genes, along with this it is as well analyzed to act so for about $5-10 \%$ of the total genome as stated by Morris and Anderson [5].

The public awareness of Vitamin D is seemed to have considerably increased; this is because of the extensive prevalence of Vitamin D defects (VDD) with accordance to the perception of Holick [7], Himmelfarb and Sayegh [8]. This prevalence is surely a matter of concern and worry and it is about the complete significance of common health having special attention on pregnancy, children, prevention of infection, and certain types of cancer as per the statement of Aguiar et al. [9]. 
In general, the vital reason of VDD is none other than the absence of exposure toward the sunlight along with sufficient ultraviolet $B$ rays (i.e., exogenous element) as per the statement given by Holick [7], Himmelfarb and Sayegh [8]. Holick [7] stated that the VDD can even get raised from a nutritional deficiency because of insufficient Vitamin $D$ intakes or else hereditary deficiencies or disorders from metabolic conversion and absorption as well. In addition to that, Gröber and Kisters [10] stated VDD relating drug is even possible because of the iatrogenic greater clearance (e.g., with carbamazepine, phenytoin, and oxcarbazepine regimens)

As per the point of view of Chapple et al. [11], when it comes to oral diseases the role played by nutrition has indeed acquired fame and popularity, furthermore, the researches made in the recent times have greatly unmasked appropriate associations amidst the oral pathologies and nutritional defects. The oral related diseases are quite complicated multifactorial diseases which also keeps the 2 major prevalent diseases all throughout the world Peres et al. [12]. The process through which Vitamin $D$ shows its effect on the oral health is not merely dependent on the system of bone metabolism.

Aim of the study is to correlate and enumerate the findings from different studies, the changes noticed in teeth in vit $D$ deficiency patients. The breakthroughs made in the recent times has led us in elaborating a review that focuses on comprehensively summarizing the prevailing evidence of impact due to deficiency of Vitamin $D$ subjected to the oral health. In addition to that, this paper of review will indeed specify the discussion made about the effect of recent researches in which the correction of VDD was applied through supplementation that may result in supporting the upcoming clinical guidelines.

\section{Vitamin D Supplementation}

Based on the research made by Moore et al. [13], the average calcium and vitamin D foods in the common people are seemed to be below the present suggestions of 1000-1200 mg and 400-600 IU everyday, respectively. Even though there is a rising consensus that such kind of everyday targets are not so sufficient [14] and the medical supplements with higher Vitamin D (800-1000 IU everyday) are now been under recommendation by the professional industries [15]. The estimation shows that nearly 1 billion people all around the world contain the deficiency or insufficiency of Vitamin D. While the advantageous effects of Vitamin D and calcium supplementation in terms of bone health are seemed to have been recognized greatly well as stated by Holick [14], the capable role of it when it comes to periodontal disease or defect, it has not been observed to be completely detected yet.

According to the viewpoint of Dietrich et al. [16], a number of researches has recommended that the intake involving calcium and/or Vitamin D leads to alleviated gingival inflammation, alveolar bone loss, or/and attachment loss. Nishida et al. [17] stated that most appropriate one are none other than the data on subjects (regarding 12,000) which has been registered in the NHANES III; that is, (Third National Health and Nutrition Examination Survey). It recommends that lesser dietary calcium food has seemed to be increasing the attachment loss in terms of dose-oriented fashion. Taking some other bigger cohort (regarding 6700 subjects), a connection that exists amid gingival inflammation and serum concentrations of D (25OHD), that is, 25-hydroxyvitamin was observed, and this is subsequently associated with the anti-inflammatory effect of Vitamin D as per the examination if [18]. The findings have even supported the capable role played by Vitamin $D$ when it comes to periodontal health. It specifies that the polymorphisms of receptor gene of Vitamin $\mathrm{D}$ have connection with the alveolar bone loss, clinical attachment, periodontitis, or/and tooth loss [19]. Therefore, there is proof which points out on the capable part played by the foods such as cod liver oil, salmon fish, egg yolks, and mushrooms relating to calcium and Vitamin $\mathrm{D}$ on dental health despite the probable impacts of that kind of dietary supplementation on the parameters of periodontal deficiency. Moreover, the results are yet to be addressed.

\section{Impact of Vitamin D Deficiency on Oral Health}

\section{Vitamin $D$ and oral health}

\section{Clinical assessment studies}

Vitamin $D$ deficiency is the vital risk element when it comes to origin of osteoporosis and that indeed may even hinder the jaws function as per the examination of Alshouibi et al. [20]. In terms of longitudinal research that was executed on about 562 adult men, the food taken every day of overall Vitamin $D$ was related to finer periodontal health. This is recorded as per the measurement taken through pocket depth, alveolar bone depth, and at last attachment loss. Over intake of Vitamin D 800 IU was connected to the lesser odds of serious periodontal deficiency, that is, (OR-0.67, 95\% $\mathrm{Cl}-0.55-0.81)$ and moderate to extreme alveolar bone loss, that is, (OR-0.54, 95\% Cl $=0.30-0.96)$ that is based on the intake.

An experiment from $3^{\text {rd }}$ NHANES regarding the cross-sectional data has proved that people possessing greatest $25(\mathrm{OH}) \mathrm{D}$ levels have gone through $20 \%$ of 
reduced bleeding on probing compared to that having lowest levels. This in turn maintains Vitamin-D's optimal range present inside of the body resulting in decrease of risk possibility like gingivitis growth through applying anti-inflammatory impacts [18]. A longitudinal research which was carried out on the people having inadequate and adequate Vitamin $D$ in examining the results of periodontal operation; teriparatide administration has proved that minimum advantages were derived from periodontal operation performed on the patients with Vitamin $D$ deficiency. Based on the findings of Bashutski et al. [21], a strong connection is seemed to be present amid the density of skeletal bone with the periodontal heath as well the success of osteointegrated implant. The report says that insufficient range of Vitamin $D$ in people would be connected to hypoplasia of atrophy and enamel present in the salivary glands. Therefore, it facilitates the dental caries growth as stated by Scardina and Messina [22]. From the outputs derived from the executed research on the basis of preschool kids, Schroth et al. [23] has made an attempt of calculating that kids with caries-free were 2 times similar to be possessing $25(\mathrm{OH})$ D concentrations (which will be around the level of $75 \mathrm{nmol} / \mathrm{L}$ ), on the other hand, children with extreme caries were observed to be 3 times more possible of possessing $25(\mathrm{OH}) \mathrm{D}$ concentrations, that is, nearly between $<35 \mathrm{nmol} / \mathrm{L}$.

Human as well as experimental researches have demonstrated a connection that exists amid insufficient status of Vitamin D along with the capable risk element for oral cancer as stated by [24]. In the process of meta-analysis, the group of people with oral squamous cell carcinoma was linked with serious Vitamin D deficiency (mean serum level $12.2 \mathrm{ng} / \mathrm{mL}$ ), as per the perspective of Grimm et al. [25]. Based on the perception of Osafi et al. [26], the functionality of antineoplastic regarding $1,25(\mathrm{OH}) 2 \mathrm{D}$ had been displayed in an extensive malignancies kind that actually include oral squamous cell carcinoma.

\section{Radiographic assessment}

Radiographic analysis Miley et al. [27] was conducted to show the Vitamin $D$ and calcium supplementation and its effects on chronic periodontitis. Relative to subjects who did not take Vitamin D and calcium supplementation, supplement takers had shallower probing depths, fewer bleeding sites, lower gingival index values, fewer furcation involvements, less attachment loss, and less alveolar crest height loss. The repeated-measures analysis indicated that collectively these differences for clinical parameters were borderline significant $(p=0.08)$. Garcia et al. [28] have applied photostimulable-phosphor and posterior bitewing radiographs for estimating the alveolar bone. The outputs agree with that fact that the supplementation of Vitamin $D$ might enhance the parameters of radiography in periodontitis suffering patients. Based on the findings of Souza et al. [29], it is recorded that the analysis made from radiographies has disclosed big pulp chambers, poorly described hypoplastic alveolar ridge and lamina dura and short roots. These kinds of dental abscesses are seemed to be quite familiar and general and thus the pulpectomy and extraction are the opted treatment. On taking the idea of Ozkan et al. [30] into consideration; dental abscesses and spontaneous gingival happen with no caries or trauma related history. Along with that the radiographic proof of grown pulp chambers coupled with pulpal horns widening beyond the dentino-enamel junction are observed to be the vital crucial oral findings as stated by the researcher.

\section{Vitamin D deficiency in tooth mineralization and caries}

Teeth are nothing but mineralized organs which is enclosed by alveolar bone and are developed by three different hard tissues such as dentin, enamel, and cementum. The mineralization process of tooth happens similar to the type of skeletal mineralization, and if in case still the mineral metabolism gets hindered then it will result in failures just alike to those which happen in the bone tissue. Vitamin $D$ has been playing a predominant vital part in the tooth and bone mineralization, and it can result in rachitic tooth when the levels get unregulated. This is nothing but a deficient as well as hypo-mineralized organ which is greatly vulnerable to decay and fracture as stated by D'Ortenzio et al. [31].

The procedure through which tooth mineralization gets affected by VDD are under big discussion and debate as per the statement made by D'Ortenzio et al. [31]. Taking the findings of Bergwitz and Jüppner [32] into consideration, it is said that the major biological base is completely dependent on the fact that extreme VDD with $(<10 \mathrm{ng} / \mathrm{mL})$ results in hypophosphatemia and hypocalcemia with secondary hyperparathyroidism that is carried by the hypocalcemia. This specific hyperparathyroidism indeed promotes renal production of $1 \alpha, 25$-dihydroxyvitamin $\mathrm{D}$ $(1,25[\mathrm{OH}] 2 \mathrm{D})$, and intestinal calcium absorption, that is, $(\mathrm{Ca} 2+)$. These leads to bone turnover increase to risen levels of serum $\mathrm{Ca}+$ as well as lesser levels of serum in terms of inorganic phosphate, that is, $(\mathrm{Pi})$ as stated by Bergwitz and Jüppner [32]. The condition of initial hypophosphatemia seemed to have then gotten extremely bad. Vitamin $D$ loss results in the signaling the track way of tooth cells carrying less $\mathrm{Ca} 2+$ concentrations and phosphate ions. Phosphate ions tend to inhibit appropriate teeth mineralization resulting in the mineralization defects as examined by Foster et al. [33].

Keeping the role of mineralization homeostasis aside, there is one more known, that is, with the help of VDR (Vitamin D receptors), Vitamin D circulation can start a signaling pathway. VDR is none other than a 
ligand-activated transcription element which is capable of controlling gene expression through the elements of Vitamin D, that is, (VDRE) as stated by Pike and Meyer [34]. For example, certain responsive genes hinder bone, immune response mineral metabolism, migration and cell life cycle, detoxification, energy metabolism, and skeletal muscle, according to the statement of Pike et al. [34], Girgis et al. [35]. Taking the outlook of Foster et al. [33] into consideration, Vitamin D tends to up-regulate VDR that subsequently persuades the structural gene elements (which includes calciumbinding proteins along with different extracellular matrix proteins) for instance: Amelogenins, enamels, dentin phosphoproteins, and dentin sialoglycoproteins. These elements lead to the formation of enamel as well as dentin.

Apart from the typical causes of VDD, reduced exposure of sunlight or the nutritional deficiency, there is certain genetic kind of defects initiating from mutation encoding elements in terms of metabolic machinery of Vitamin $\mathrm{D}$. The main reason of VDD, next to the genetic mutations are observed to be abnormal secretion of enzyme (Vitamin D-dependent rickets type 1, VDDR-I) and anomalous signaling or functioning of VDR (Vitamin D-dependent rickets type 2, VDDR-Ila; hereditary defects in the Vitamin $D$ receptor-effector system, HDVDR) [33]. On the basis of research made by Foster et al. [33]; these kind of genetic states leads to causing deficient mineralized tissues in spite of the normal consumption of Vitamin $D$ and sunlight exposure. This will ultimately result in increasing the risk of hypoplasia (mineralized tooth tissue) which is none other than enamel hypoplasia, dentinogenesis imperfecta, amelogenesis imperfecta, or else greater caries risk.

According to the perception of Schroth et al. [36], deciduous dentition can remarkably get influenced by the levels of maternal $25(\mathrm{OH}) \mathrm{D}$; in spite of the control by inherited deficiency of the unborn. Serum-circulating Vitamin D levels of the fetus persuade the maternal concentration and thus shall be utilized like a standard surrogate marker to the unborn baby as examined by Hollist and Pittardm [37]. Thus, if in case the levels of maternal $25(\mathrm{OH}) \mathrm{D}$ gets unbalanced that might cause a direct repercussions on the health of the baby [38], particularly on the development of tooth; says [36], [39]. The pattern in terms of mineralization fault is based on particular gestation work at the time of occurrence of maternal VDD. For instance; during $13^{\text {th }}$ week (in approx.) from conception; calcification gets started by the primary maxillary central incisor of humans. Along with that if in case there is VDD status; possibilities of mineralization/hypoplasia defect are there on the incisal $3^{\text {rd }}$ of crown. In the present times, its quite known that maternal VDD at the stage of 12-16; 20-32; and 36-40 weeks ends up in deficiency at the incisal $3^{\text {rd }}$; mid- $3^{\text {rd }}$; and cervical $3^{\text {rd }}$, respectively [39]. On taking a randomized clinical trial also known as RCT, the supplementation of vitamin $D$ at the time of pregnancy has disclosed the fact that pregnant ladies having Vitamin D (<15 ng/mL) possessed 14\% greater risk of suffering deciduous dentition [39]. Contrast to that, high dosage Vitamin D supplementation in pregnancy was linked with an average of $50 \%$ alleviated odds of enamel deficiency [40], [41]. In another case of RCT, high dosage of Vitamin D supplementation at the time of pregnancy has close association to almost 50\% lesser enamel deficiency risks for in the newly born children. This is primary preventive role played by Vitamin $D$ for enamel deficiency [40].

In addition to that, caries that are left untreated in permanent as well as deciduous teeth were the best prevalent state which hinders $35 \%$ and $9 \%$ of the entire worldwide population, respectively, as examined by Kassebaum et al. [42]. Petersen [43] examined that furthermore as per World Health Organization; caries is the $4^{\text {th }}$ most costly chronic disease to be treated. This disease is infectious which contains multifactorial as well as complex etiology. According to the perception of Selwitz et al. [44]; environmental elements such as cariogenic diet having high content of carbohydrate, cariogenic bacteria, and bad oral hygiene were observed to be the most extensively researched risk factors. In the outlook of Rosier et al. [45], nonetheless, certain patients seemed to be very much resistant or susceptible to caries compared to others while getting exposed to same kind of environmental risk elements. In the present times, the proof emphasis the connection low Vitamin D levels as well as the greater prevalence level of caries in adults and also children. However, the procedure or the mechanism yet remains being confusing or unclear as per the view of Zhou et al. [46], Herzog et al. [47].

On the basis of the study made by Schroth et al. and Wójcik et al. [23], [48], Vitamin D, furthermore, exerts many roles in the point of human immune system control. Along with that an optimal concentration of Vitamin $D$ is connected to the lower odds for the dental caries in kids. Anyhow the results of the research look contradictory in the perspective of Girgis et al. [36], Herzog et al. [47], Gyll et al. [49]. A systematic review was made in the recent times regarding controlled clinical trials holding the data of 2827 kids. They analyzed the impact of Vitamin D supplementation in terms of prevention process of dental caries examined [50], [51]. The outputs of this research prove that the supplementation of Vitamin D alleviated the caries' risk in nearly $47 \%$ but the predictability is low as stated by Hujoel [50]. Based on the findings of Schroth et al. [23], one more study encourages that kids who are free from caries were 2 times possible of having optimal concentrations of Vitamin D ( $\geq 75 \mathrm{nmol} / \mathrm{L})$, whereas the kids having serious caries right from early childhood are likely to be having almost thrice the odds of possessing deficiency levels, that is, ( $<35 \mathrm{nmol} / \mathrm{L})$. Whereas it is mandatory and crucial to clear that the 
main teeth structure is not been changed by the serum Vitamin $D$ as this particular structure is left being constant till certain extrinsic elements results its wear. In spite of the fact that Vitamin D evidently prevents the caries lesions with the help of immune regulation that subsequently promotes microbial eradication along with peptide functioning as per the above made discussion.

According to the examination of Altman [52], the part played by both AMPs (antimicrobial peptides) and UVB in terms of cariogenic bacteria decrease had been in research. In the perception of Altman [52], Wong et al. [53], the procedure that involves UVB lessens the risk factor in terms of dental caries. This is possibly with Vitamin D production accompanied by AMPs induction that possesses antimicrobial attributes. AMPs are none other than the host defense peptides mostly amphiphilic and cationic molecules. These are the necessary factors when it comes to innate immunity fighting against many types of viruses, fungi, and bacteria as stated by Wong et al. and Grant [53], [54]. The researches looks to emphasis on AMPs combination instead of particular part of an individual AMP as per [55] and [56] proposed it as a capable/potential application for both dental caries' prevention as well as treatment. As per the sayings of Wong et al. [53], Streptococcus mutans was significantly nothing but a main etiological agent belonging to the dental caries, this might tend to with stand host salivary (APSs). That in turn describes about the virulence of it in the subject of dental caries pathophysiology.

\section{Conclusion}

Vitamin D plays a major role for oral health; therefore, individuals need to ensure the balanced diet of Vitamin $D$ in their food as to manage the oral defects. The reviews point out that the VDD was majorly implicated with oral diseases and has been associated with the major issue of tooth defects, failure of oral treatment, caries, and oral manifestations. Hence, the doctors need to confirm the Vitamin $D$ level before the treatment of any oral conditions to deserve successful outcomes of treatment.

\section{References}

1. Borel P, Caillaud D, Cano NJ. Vitamin D bioavailability: State of the art. Crit Rev Food Sci Nutr. 2015;55(9):1193-205. PMid:24915331

2. Holick MF, Chen TC. Vitamin D deficiency: A worldwide problem with health consequences. Am J Clin Nutr. 2008;87(4):1080S-6. PMid: 18400738
3. Turck D, Bresson J, Burlingame B, Dean T, Fairweather-Tait S, Heinonen $\mathrm{M}$, et al. Update of the tolerable upper intake level for vitamin D for infants. EFSA J. 2018;16(8):e05365. https://doi. org/10.2903/j.efsa.2018.5365

4. Lanham-New SA, Wilson LR. Vitamin D - has the new dawn for dietary recommendations arrived? Nutr Bull. 2016;41:2-5. https://doi.org/10.1111/nbu.12185

5. Morris HA, Anderson PH. Autocrine and paracrine actions of Vitamin D. Clin Biochem Rev. 2010;31(4):129-38.

PMid:21170259

6. Richard CL, Farach-Carson MC, Rohe B, Nemere I, Meckling KA Involvement of 1,25D3-MARRS (membrane associated, rapid response steroid-binding), a novel Vitamin $D$ receptor, in growth inhibition of breast cancer cells. Exp Cell Res. 2010;316(5):695703. https://doi.org/10.1016/j.yexcr.2009.12.015

PMid:20036234

7. Holick MF. Vitamin D deficiency. $N$ Engl J Med. 2007;357(3):266-81.

PMid: 17634462

8. Himmelfarb J, Sayegh MH. Chronic Kidney Disease, Dialysis, and Transplantation. Amsterdam: Elsevier; 2010. p. 721-37.

9. Aguiar M, Andronis L, Pallan M, Högler W, Frew E. The economic case for prevention of population Vitamin D deficiency: A modelling study using data from England and Wales. Eur J Clin Nutr. 2020;74(5):825-33. https://doi.org/10.1038/ s41430-019-0486-x

10. Gröber U, Kisters K. Influence of drugs on Vitamin D and calcium metabolism. Dermatoendocrinology. 2012;4(2):158-66. PMid:22928072

11. Chapple IL, Bouchard P, Cagetti MG, Campus G, Carra MC, Cocco F, et al. Interaction of lifestyle, behaviour or systemic diseases with dental caries and periodontal diseases: Consensus report of group 2 of the joint EFP/ORCA workshop on the boundaries between caries and periodontal diseases. J Clin Periodontol. 2017;44 Suppl 18:S39-51. https://doi. org/10.1111/jcpe.12685

PMid:28266114

12. Peres MA, Macpherson LM, Weyant RJ, Daly B, Venturelli $R$, Mathur MR, et al. Oral diseases: A global public health challenge. Lancet. 2019;394(10194):249-60. https://doi.org/10.1016/ s0140-6736(19)31146-8

PMid:31327369

13. Moore C, Murphy MM, Keast DR, Holick MF. Vitamin D intake in the United States. J Am Diet Assoc. 2004;104(6):980-3.

PMid: 15175600

14. Holick MF. Resurrection of Vitamin D deficiency and rickets. J Clin Invest. 2006;116(8):2062-72.

PMid: 16886050

15. National Osteoporosis Foundation. Calcium and Vitamin D. Arlington, VA: National Osteoporosis Foundation; 2018.

16. Dietrich T, Joshipura KJ, Dawson-Hughes B, BischoffFerrari HA. Association between serum concentrations of 25-hydroxyvitamin D3 and periodontal disease in the US population. Am J Clin Nutr. 2004;80(1):108-13. PMid:15213036

17. Nishida M, Grossi SG, Dunford RG, Ho AW, Trevisan M, Genco RJ. Calcium and the risk for periodontal disease. J Periodontol. 2000;71(7):1057-66. https://doi.org/10.1902/ jop.2000.71.7.1057 PMid: 10960010

18. Dietrich T, Nunn M, Dawson-Hughes B, Bischoff-Ferrari HA Association between serum concentrations of 25-hydroxyvitamin D and gingival inflammation. Am J Clin Nutr. 2005;82(3):575-80. https://doi.org/10.1093/ajcn.82.3.575 


\section{PMid: 16155270}

19. Inagaki K, Krall EA, Fleet JC, Garcia RI. Vitamin D receptor alleles, periodontal disease progression, and tooth loss in the VA dental longitudinal study. J Periodontol. 2003;74(2):161-7. https://doi.org/10.1902/jop.2003.74.2.161

PMid:12666703

20. Alshouibi EN, Kaye EK, Cabral HJ, Leone CW, Garcia RI. Vitamin D and periodontal health in older men. J Dent Res. 2013;92(8):689-93. https://doi.org/10.1177/0022034513495239 PMid:23788610

21. Bashutski JD, Eber RM, Kinney JS, Benavides E, Maitra S, Braun TM, et al. Teriparatide and osseous regeneration in the oral cavity. N Engl J Med. 2010;363(25):2396-405. https://doi. org/10.1056/nejmoa1005361

22. Scardina GA, Messina P. Good oral health and diet. J Biomed Biotechnol. 2012;2012:720692.

PMid:22363174

23. Schroth RJ, Levi JA, Sellers EA, Friel J, Kliewer E, Moffatt ME. Vitamin $D$ status of children with severe early childhood caries: A case-control study. BMC Pediatr. 2013;13(1):174. https://doi. org/10.1186/1471-2431-13-174

PMid:24160554

24. Kingsley K, O'Malley S, Ditmyer M, Chino M. Analysis of oral cancer epidemiology in the US reveals state-specific trends: Implications for oral cancer prevention. BMC Public Health. 2008;8(1):87. https://doi.org/10.1186/1471-2458-8-87 PMid:18331638

25. Grimm M, Cetindis M, Biegner T, Lehman M, Munz A, Teriete $P$, et al. Serum Vitamin $D$ levels of patients with oral squamous cell carcinoma (OSCC) and expression of vitamin D receptor in oral precancerous lesions and OSCC. Med Oral Patol Oral Cir Bucal. 2015;20(2):e188-95. https://doi.org/10.4317/medoral.20368 PMid:25662556

26. Osafi J, Hejazi A, Stutz DD, Keiserman MA, Bergman CJ, Kingsley K. Differential effects of 1,25-dihydroxyvitamin D3 on oral squamous cell carcinomas in vitro. J Diet Suppl. 2014;11(2):14554. https://doi.org/10.3109/19390211.2013.859209 PMid:24670118

27. Miley DD, Garcia MN, Hildebolt CF, Shannon WD, Couture RA, Anderson Spearie CL, et al. Cross-sectional study of Vitamin D and calcium supplementation effects on chronic periodontitis. J Periodontol. 2009;80(9):1433-9. https://doi.org/10.1902/ jop.2009.090077

PMid:19722793

28. Garcia MN, Hildebolt CF, Miley DD, Dixon DA, Couture RA, Anderson Spearie CL, et al. One-year effects of Vitamin D and calcium supplementation on chronic periodontitis. J Periodontol. 2011;82(1):25-32. https://doi.org/10.1902/jop.2010.100207 PMid:20809866

29. Souza AP, Kobayashi TY, Lourenço Neto N, Silva SM, Machado MA, Oliveira TM. Dental manifestations of patient with Vitamin D-resistant rickets. J Appl Oral Sci. 2013;21(6):601-6. https://doi.org/10.1590/1679-775720130249

PMid:24473729

30. Ozkan S, Ucok Z, Alagöl F. Dental manifestations of familial hypophosphatemic vitamin-D-resistant rickets: Report of case. ASDC J Dent Child. 1984;51:448-50.

31. D'Ortenzio L, Kahlon B, Peacock T, Salahuddin H, Brickley M. The rachitic tooth: Refining the use of interglobular dentine in diagnosing vitamin D deficiency. Int J Paleopathol. 2018;22:101 8. https://doi.org/10.1016/j.ijpp.2018.07.001 PMid:30048808

32. Bergwitz $\mathrm{C}$, Jüppner $\mathrm{H}$. Regulation of phosphate homeostasis by PTH, Vitamin D, and FGF23. Annu Rev Med. 2010;61(1):91-104. https://doi.org/10.1146/annurev.med.051308.111339

PMid:20059333

33. Foster BL, Nociti FH, Somerman MJ. The rachitic tooth. Endocr Rev. 2014;35(1):1-34.

PMid:23939820

34. Pike JW, Meyer MB. The Vitamin D receptor: New paradigms for the regulation of gene expression by 1,25-dihydroxyvitamin D3. Rheum Dis Clin North Am. 2012;38(1):13-27.

PMid:22525840

35. Girgis CM, Clifton-Bligh RJ, Hamrick MW, Holick MF, Gunton JE. The roles of vitamin $d$ in skeletal muscle: Form, function, and metabolism. Endocr Rev. 2013;34(1):33-83. https://doi. org/10.1210/er.2012-1012 PMid:23169676

36. Schroth RJ, Lavelle C, Tate R, Bruce S, Billings RJ, Moffatt MEK. Prenatal Vitamin D and dental caries in infants. Pediatrics. 2014;133(5):e1277-84. https://doi.org/10.1542/peds.2013-2215 PMid:24753535

37. Hollist BW, Pittardm W. Evaluation of the total fetomaternal Vitamin D relationships at term: Evidence for racial differences. J Clin Endocrinol Metab. 1984;59(4):652-7. PMid:6090493

38. Karras SN, Fakhoury H, Muscogiuri G, Grant WB, van den Ouweland JM, Colao AM, et al. Maternal Vitamin D levels during pregnancy and neonatal health: Evidence to date and clinical implications. Ther Adv Musculoskelet Dis. 2016;8(4):124-35. https://doi.org/10.1177/1759720x16656810 PMid:27493691

39. Reed SG, Voronca D, Wingate JS, Murali M, Lawson AB, Hulsey TC, et al. Prenatal Vitamin D and enamel hypoplasia in human primary maxillary central incisors: A pilot study. Pediatr Dent J. 2017;27(1):21-8. https://doi.org/10.1016/j.pdj.2016.08.001 PMid:30100673

40. Nørrisgaard PE, Haubek D, Kühnisch J, Chawes BL, Stokholm J, Bønnelykke K, et al. Association of high-dose Vitamin $D$ supplementation during pregnancy with the risk of enamel defects in offspring: A 6-year follow-up of a randomized clinical trial. JAMA Pediatr. 2019;173(10):924-30. https://doi. org/10.1001/jamapediatrics.2019.2545

PMid:31381020

41. Tanaka K, Hitsumoto S, Miyake $\mathrm{Y}$, Okubo H, Sasaki S, Miyatake $\mathrm{N}$, et al. Higher Vitamin $\mathrm{D}$ intake during pregnancy is associated with reduced risk of dental caries in young Japanese children. Ann Epidemiol. 2015;25(8):620-5. https:// doi.org/10.1016/j.annepidem.2015.03.020 PMid:25956333

42. Kassebaum NJ, Bernabé E, Dahiya M, Bhandari B, Murray CJ, Marcenes W. Global burden of untreated caries: A systematic review and metaregression. J Dent Res. 2015;94(5):650-8. https://doi.org/10.1177/0022034515573272 PMid:25740856

43. Petersen PE. World Health Organization global policy for improvement of oral health--World Health Assembly 2007. Int Dent J. 2008;58(3):115-21. https://doi.org/10.1111/j.1875595x.2008.tb00185.x PMid: 18630105

44. Selwitz RH, Ismail Al, Pitts NB. Dental caries. Lancet. 2007;369(9555):51-9. s0140-6736(07)60031-2 PMid: 17208642

45. Rosier BT, Marsh PD, Mira A. Resilience of the oral microbiota in health: Mechanisms that prevent dysbiosis. J Dent Res. 2018;97(4):371-80. https://doi.org/10.1177/0022034517742139 PMid:29195050 
46. Zhou F, Zhou Y, Shi J. The association between serum 25-hydroxyvitamin D levels and dental caries in US adults. Oral Dis. 2020;26(7):1537-47. https://doi.org/10.1111/odi.13360 PMid:32304260

47. Herzog K, Scott JM, Hujoel P, Seminario AL. Association of Vitamin $D$ and dental caries in children: Findings from the National Health and Nutrition Examination Survey, 2005-2006. J Am Dent Assoc. 2016;147(6):413-20.

PMid:26827077

48. Wójcik D, Krzewska A, Szalewski L, Pietryka-Michałowska E, Szalewska M, Krzewski S, et al. Dental caries and Vitamin D3 in children with growth hormone deficiency. Medicine (Baltimore). 2018;97(8):e9811. https://doi.org/10.1097/ md.0000000000009811

\section{PMid:29465564}

49. Gyll J, Ridell K, Öhlund I, Karlsland Åkeson P, Johansson I, Lif Holgerson P. Vitamin D status and dental caries in healthy Swedish children. Nutr J. 2018;17(1):11. https://doi.org/10.1186/ s12937-018-0318-1

PMid:29338758

50. Hujoel PP. Vitamin D and dental caries in controlled clinical trials: Systematic review and meta-analysis. Nutr Rev. 2013;71(2):8897. https://doi.org/10.1111/j.1753-4887.2012.00544.x PMid:23356636

51. Kühnisch J, Thiering E, Heinrich-Weltzien R, Hellwig E, Hickel R, Heinrich J. Fluoride/vitamin D tablet supplementation in infants-effects on dental health after 10 years. Clin Oral

Investig. 2017;21(7):2283-90. https://doi.org/10.1007/
s00784-016-2021-y
PMid:27928689

52. Altman H. In vitro assessment of antimicrobial peptides as potential agents against several oral bacteria. J Antimicrob Chemother. 2006;58(1):198-201. https://doi.org/10.1093/jac/ dkl181

PMid:16687459

53. Wong J, Ye X, Ng T. Cathelicidins: Peptides with antimicrobial, immunomodulatory, anti-inflammatory, angiogenic, anticancer and procancer activities. Curr Protein Pept Sci. 2013;14(6):50414. https://doi.org/10.2174/13892037113149990067 PMid:23968350

54. Grant WB. A review of the role of solar ultraviolet-B irradiance and vitamin $D$ in reducing risk of dental caries. Dermatoendocrinology. 2011;3(3):193-8.

PMid:22110779

55. Colombo NH, Ribas LF, Pereira JA, Kreling PF, Kressirer CA Tanner AC, et al. Antimicrobial peptides in saliva of children with severe early childhood caries. Arch Oral Biol. 2016;69:40-6. https://doi.org/10.1016/j.archoralbio.2016.05.009 PMid:27232359

56. Chen Z, Yang G, Lu S, Chen D, Fan S, Xu J, et al. Design and antimicrobial activities of LL-37 derivatives inhibiting the formation of Streptococcus mutans biofilm. Chem Biol Drug Des. 2019;93(6):1175-85. https://doi.org/10.1111/cbdd.13419 PMid:30635992 